\title{
Immunohistochemical localization of glucagon and pancreatic polypeptide on rat endocrine pancreas: coexistence in rat islet cells
}

\author{
Y.H. Huang, M.J. Sun, M. Jiang, B.Y. Fu \\ Department of Gastroenterology, The First Affiliated Hospital, China Medical University, Shenyang, China
}

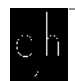

(C2009 European Journal of Histochemistry

We used immunofluorescence double staining method to investigate the cellular localization of glucagon and pancreatic polypeptide (PP) in rat pancreatic islets. The results showed that both A-cells (glucagon-secreting cells) and PP-cells (PPsecreting cells) were located in the periphery of the islets. However, A-cells and PP-cells had a different regional distribution. Most of A-cells were located in the splenic lobe but a few of them were in the duodenal lobe of the pancreas. In contrast, the majority of PP-cells were found in the duodenal lobe and a few of them were in the splenic lobe of the pancreas. Furthermore, we found that $67.74 \%$ A-cells had PP immunoreactivity, $70.92 \%$ PP-cells contained glucagon immunoreactivity with immunofluorescence double staining. Our data support the concept of a common precursor stem cell for pancreatic hormone-producing cells.

Key words: glucagon, pancreatic polypeptide, rat, pancreas, Immunofluorescence double staining histochemistry.

Correspondence: Jiang Min,

Department of Gastroenterology,

The First Affiliated Hospital, China Medical University, Shenyang 110001, China

Tel.: +86.24.8328.2554.

Fax: +86.24.2326.7030.

E-mail: jiangminhyh@hotmail.com

Paper accepted on 20 May, 2009

European Journal of Histochemistry

2009; vol. 53 issue 2 (April-June): 81-86
T he pancreatic islet is comprised of numerous cell types that synthesize and secrete distinct peptide hormones. Four major cell types are recognized in pancreatic islets of many mammalian species including rat, A-cells which contain glucagon, B-cells which contain insulin, D-cells which contain somatostatin, and PP-cells which contain the pancreatic polypeptide (PP) (Erlandsen, 1980; Reddy et al., 1988).

Previous studies have revealed coexistence of glucagon- and PP-like immunoreactivity in endocrine pancreas cells of frog, rat, baboon, murine, monkey, and fish (Kaung and Elde, 1980; Kaung, 1985a, 1985b; Wolfe-Coote et al., 1988; Herrera et al., 1991; Lozano et al., 1991; Park and Bendayan, 1992; Louw et al., 1997). However, those experiments were performed by staining adjacent ultrathin sections with anti-glucagon serum and anti-PP serum respectively by peroxidase antiperoxidase (PAP) or immuno-gold labeling or avidin-biotin-peroxidase method, and the situation of two kinds of positive cells were compared.

It is still not clear whether one cell type contains two or more peptides. Therefore, we used immunofluorescence double staining to identify the peptides secreted by single specific cells. This is the first time that coexistence of glucagon and PP in rat islet cells has been detected by an immunofluorescence double staining method.

\section{Materials and Methods}

\section{Animals}

Male Sprague-Dawley rats $(n=9,180-200$ g, 6-7 weeks) were obtained from China Medical University. All experiments were carried out according to the Guidelines for Animal Experimentation at China Medical University. They were housed in temperature-, humidity-, and light-controlled rooms $\left(23 \pm 1{ }^{\circ} \mathrm{C}, 50 \pm 5 \%\right.$, and light on from 8:00 a.m. to 8:00 p.m.), and had free access to standard food 
and tap water. All efforts were made to minimize the number of animals used and their suffering. Animals were not starved of food or water before they were killed in this study.

\section{Primary antibodies}

Sheep antibody against human glucagon was bought from Biogenesis Ltd (4660-0930, Biogenesis, Poole, England); this antibody had been previously used by others for immunocytochemical studies (Brar et al., 1989; Göpel et al., 1999; Dalle et al., 2002; Oshima et al., 2006). Guinea pig antibody against rat $\mathrm{PP}$ was bought from Lincoresearch Ltd (4040-01, Lincoresearch, Charles, M0, USA); this antibody too had been previously used by others for immunocytochemical studies (Zhang et al., 2000; Hayashi et al., 2003; Mrejen et al.,2005).

\section{Preabsorption test}

$100 \mu \mathrm{g}$ of synthetic glucagon (G2044, Sigma, St Louis, USA) and rat PP (P6410, Sigma, St Louis, USA) was added to $1 \mathrm{ml}$ of diluted antisera, and incubated for 24 hours at $4^{\circ} \mathrm{C}$. Using this preabsorbed antisera, sections of the pancreas were processed for immunofluorescence histochemistry as described below.

\section{Immunofluorescence double staining histochem- istry}

Nine rats were anesthetized with sodium pentobarbital (60 mg/kg body weight, i.p.), and perfused through the ascending aorta with $300 \mathrm{~mL}$ of a fixative solution containing $4 \%$ paraformaldehyde in $0.1 \mathrm{M}$ phosphate buffer ( $\left.\mathrm{PB}, \mathrm{pH} 7.4,4^{\circ} \mathrm{C}\right)$. The pancreases were divided into the duodenal lobe and the spleen splenic lobe. $10 \mu \mathrm{m}$ thick sections were cut using a cryostat (Cryocut 1800, Reichert-Jung, Heiderberg, Germany).

Double staining of glucagon and PP was performed as follows. Sections were incubated in the following solutions: (1) $0.3 \%$ Triton X-100 in PBS for 30 minutes at room temperature; (2) $5 \%$ normal donkey serum in PBS for 1 hour at room temperature; (3) a mixture of primary antisera: sheep anti-glucagon antiserum (1:200), and guinea pig anti-PP antiserum $(1: 12,000)$ for 48 hours at $4^{\circ} \mathrm{C}$; (4) a mixture of secondary antisera: FITCconjugated donkey anti-sheep IgG (AP184F, Chemicon, Temecula, CA, USA, 1:200), and Cy3conjugated donkey anti-guinea pig IgG (AP193C,
Chemicon, 1:200) for 2 hours at room temperature. Finally, glucagon was labeled with FITC (green), PP was labeled with Cy3 (red). The stained sections were observed under a confocal laser scanning microscope (LSM510, Zeiss, Jena, Germany). Equipped with filters of $543 \mathrm{~nm}$ to $570 \mathrm{~nm}$ for Cy 3 (red) and $448 \mathrm{~nm}$ to $525 \mathrm{~nm}$ for FITC (green).

\section{Statistical analysis}

Eighteen stained sections (2 sections per region from each rat) were observed. Data from 100 islets (6-12 islets per section) were analyzed. Numbers of cells were counted in random fields of vision, using the selective filters ( $\times 40$ or $\times 63$ objective, $\times 10$ eyepiece). The results are presented as mean values \pm SEM. Statistical analysis was performed by comparing groups of data with Student's t-test, where $p<0.05$ was regarded as significant.

\section{Results}

Figure 1 shows the cellular localization of glucagon and PP in rat pancreatic islets. A-cells were located in the periphery of the duodenal lobe (Figure 1c) and splenic lobe (Figure 1d) of the islets. PP-cells were also found to be arranged at the periphery of the duodenal lobe (Figure la) and splenic lobe (Figure $1 \mathrm{~b}$ ) of the islets. The majority of A-cells were located in the splenic lobe and a few of them were in the duodenal lobe of the pancreas. Average number of A-cells for each islet is 16.9 in the duodenal lobe, and 25.84 in the splenic lobe. However, a few of the PP-cells were located in the splenic lobe of the pancreas and most of PP-cells were in the duodenal lobe. Average number of PPcells for each islet is 22.7 in the duodenal lobe, and 18.12 in the splenic lobe (Table 1 ). $67.74 \%$ A-cells were also positive for PP, while $70.92 \%$ PP-cells contained glucagon immunoreactivity (Table 2 ).

Preabsorption of the antisera with glucagon and $P P$ eliminated the immunostaining (Figure $2 b, 2 e$ ).

\section{Discussion}

Four major types of cells are recognized in pancreatic islets of many mammalian species including rat. A-cells are arranged in clusters scattered the periphery of the islets, and B-cells occupy the cen- 

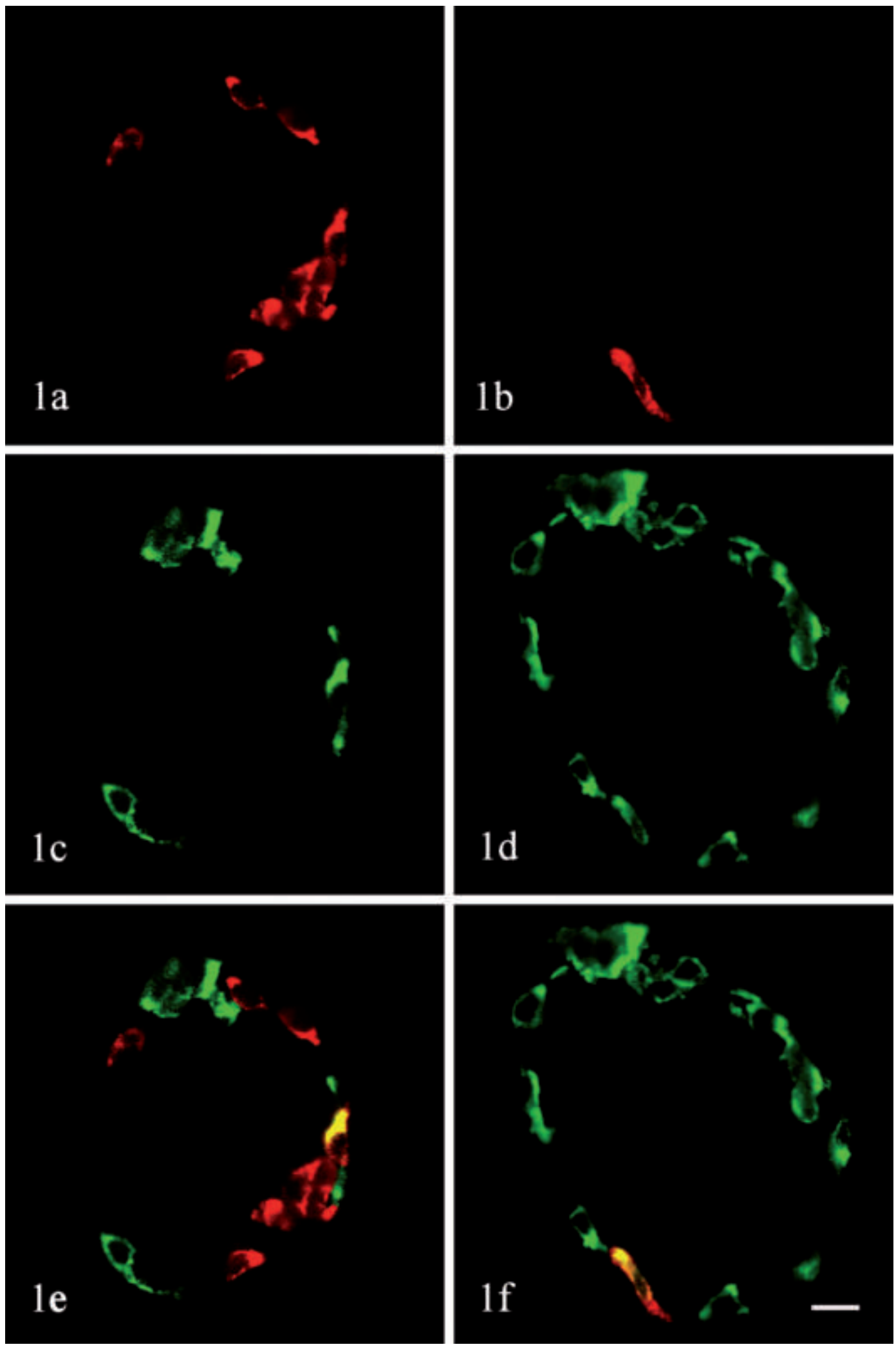

Figure 1. Localization of glucagon and PP in rat pancreatic islets by immunohistochemistry. Sections were stained with an immunofluorescence double staining method in combination of anti-glucagon (FITC) and anti-PP (Cy3), and then observed with a confocal laser scanning microscope. (a, c, e) islet in the duodenal lobe. (b, d, f) islet in the splenic lobe. (a, b) PP staining (red). (c, d) glucagon staining (green). (e, f) Superimposition of the images in panels a and $\mathbf{c}, \mathbf{b}$ and d. Note that both of A-cells and PP-cells were located at the periphery of the islets. A few of A-cells were found in the duodenal lobe of the pancreas and most A-cells were in the splenic lobe, Most of PPcells were located in the duodenal lobe and a few of them were in the splenic lobe of the pancreas. Glucagon and PP are colocalized in some rat islet cells $(e, f)$. Original magnification $\times 630$. Bar $=10 \mu \mathrm{m}$. 
tral portion of the islets. Most of the D-cells are located peripherally, while a few of them are found in the between. PP-cells are found either individually or in clusters at the periphery of the islets (Elayat et al. 1995).

In the present study, we found that both of A-cells and PP-cells were located in the periphery of the islets with an immunofluorescence double staining method. In addition, we found that a few of A-cells were located in the duodenal lobe of the pancreas and the majority of the cells were in the splenic lobe. Average number of A-cells for each islet is 16.9 in the duodenal lobe, and 25.84 in the splenic lobe. However, a few of PP-cells were found in the splenic lobe of the pancreas and most of them were in the duodenal lobe. Average number of PP-cells for each islet is 22.7 in the duodenal lobe, and 18.12 in the splenic lobe. Our results are similar to those from other researchers (Orci et al., 1976; Louw et al., 1997).

The coexistence of glucagon- and PP-like immunoreactivity in endocrine pancreas cells has
Table 1. Number of cell in different regions of rat pancreas ( number of pancreas used $=9$ ).

\begin{tabular}{lcccc}
\hline & \multicolumn{2}{c}{ Splenic lobe (islet number=100 } & \multicolumn{2}{c}{ Duodenal lobe (islet number=100) } \\
\hline Cell type & Per islet number & Total number & Per islet number & Total number \\
\hline Glu+PP- & $10.89 \pm 9.19$ & 1089 & $2.9 \pm 3.89$ & 290 \\
Glu+PP+ & $14.95 \pm 12.99$ & 1495 & $14 \pm 15.71$ & 1400 \\
Glu-PP+ & $3.17 \pm 3.14$ & 317 & $8.7 \pm 9.44$ & 870 \\
Total A-cells** & $25.84 \pm 16.42$ & 2584 & $16.9 \pm 16.91$ & 1690 \\
Total PP-cells* & $18.12 \pm 14.61$ & 1812 & $22.7 \pm 16.45$ & 2270 \\
& & & & \\
\hline
\end{tabular}

${ }^{*} p<0.05,{ }^{*} p<0.001$

Table 2. Coexistence rate.

\begin{tabular}{lll}
\hline A-cells PP positive rate & Glu+PP+/Total A-cells & $67.74 \%$ \\
PP-cells Glucagon positive rate & Glu+PP+/Total PP-cells & $70.92 \%$ \\
\hline
\end{tabular}

already been demonstrated in amphibians, mammals, and fish (Kaung and Elde, 1980; Kaung, 1985a, 1985b; Wolfe-Coote et al., 1988; Herrera et al., 1991; Lozano et al., 1991; Park and Bendayan, 1992; Louw et al., 1997), by comparing the immunolabeling for either antigen in adjacent
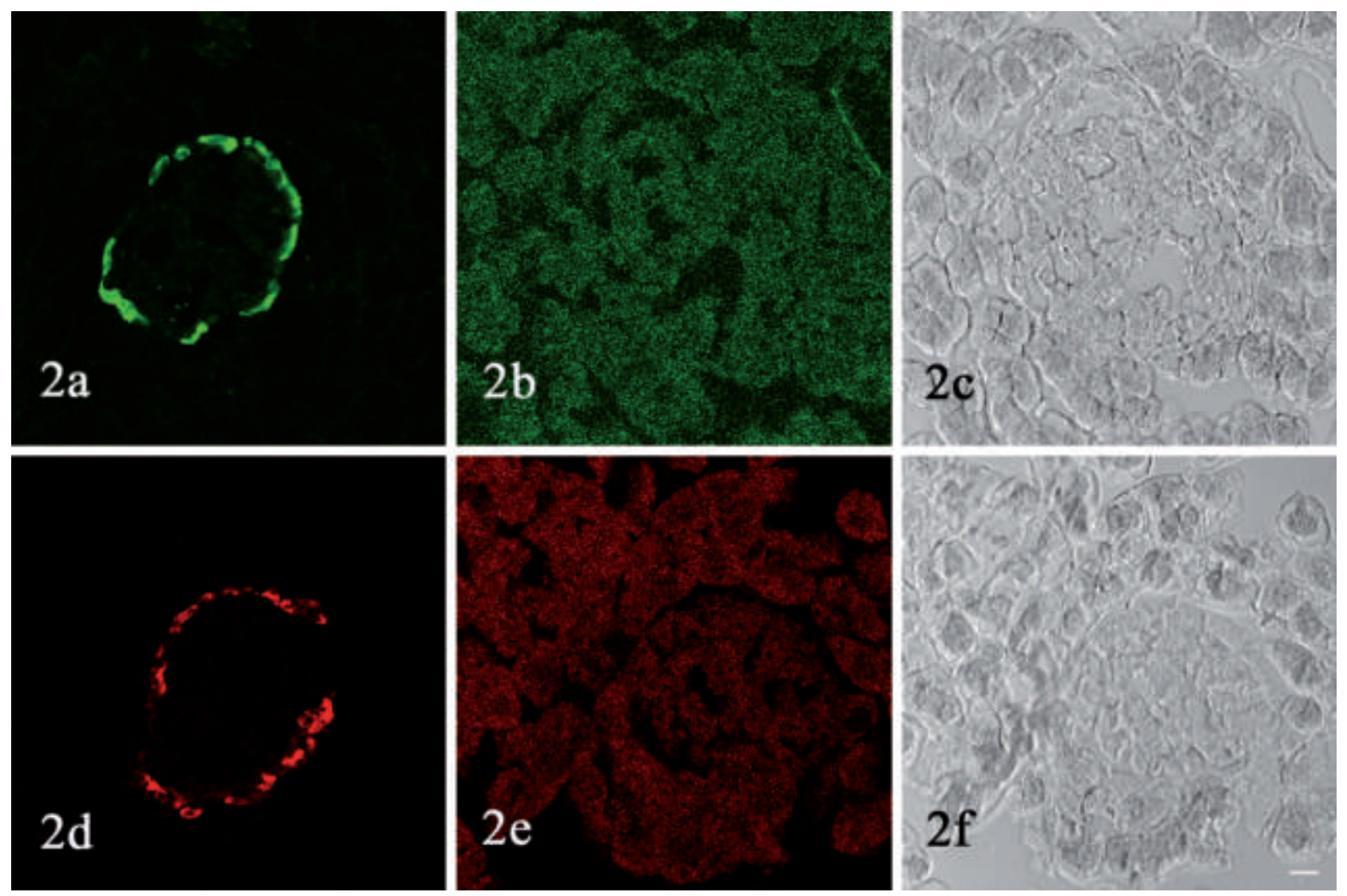

Figure 2. Preabsorption test. Sections of rat pancreas are processed for immunofluorescence histochemistry using non-absorbed antiglucagon antiserum (a), anti-PP antiserum (d), and antisera preabsorbed with synthetic glucagon (b) or rat PP (e). Preabsorption eliminate the immunostaining $(b, e) .(c, f)$ are DIC image of $(b, e)$. Original magnification $\times 400$. Bar $=20 \mu \mathrm{m}$ 
ultrathin sections.

For the first time, to our best knowledge, the dual-immunofluorescence method used in the present investigation allowed not only to confirm that glucagon and PP may coexist in the same cell but also made it possible to estimate the high percentage of A-cells expressing PP immunoreactivity and that of PP-cells containing glucagon. These data support the concept of a common precursor stem cell for pancreatic hormone-producing cells (Lukinius et al., 1992).

Ontogenic studies have shown that the first immunoreaction in rat fetal pancreas occurs for glucagon on day E11.5, for insulin on day E12.5, and for somatostatin on day E15.5, while PP cells are found soon after birth (Sundler et al., 1977; Yoshinari and Daikoku, 1982). Yang et al. (2002) presented evidence that highly purified adult rat hepatic oval "stem" cells, which are capable of differentiation to hepatocytes and bile duct epithelium, can trans-differentiate into pancreatic endocrine hormone-producing cells when cultured in a high-glucose environment. Eberhard et al. (2008) described an explant culture system in which beta-cells and other endocrine cells appeared in the duct epithelium. Evidence for an origin from the duct epithelium is threefold.

The coexistence of glucagon and PP in some islet cells, indicates the relationship of the two peptides in phylogeny. It also suggests a close biochemical and/or functional relationship between the two peptides. Further investigation in this area is warranted.

\section{References}

Brar AK, Brinster RL, Frohman LA. Immunohistochemical analysis of human growth hormone-releasing hormone gene expression in transgenic mice. Endocrinology 1989;125:801-9.

Dalle S, Fontés G, Lajoix AD, LeBrigand L, Gross R, Ribes $G$, et al. Miniglucagon (glucagon 19-29): a novel regulator of the pancreatic islet physiology. Diabetes 2002;51:406-12.

Eberhard D, Tosh D, Slack JM. Origin of pancreatic endocrine cells from biliary duct epithelium. Cell Mol Life Sci 2008 ;65:3467-80.

Elayat AA, el-Naggar MM, Tahir M. An immunocytochemical and morphometric study of the rat pancreatic islets. J Anat 1995;186:629-37.

Erlandsen SL. Types of pancreatic islet cells and their immunocytochemical identification. Monogr Pathol 1980;21:140-55.
Göpel S, Kanno T, Barg S, Galvanovskis J, Rorsman P. Voltage-gated and resting membrane currents recorded from B-cells in intact mouse pancreatic islets. J Physiol 1999; Dec15;521 (Pt 3):717-28.

Hayashi M, Otsuka M, Morimoto R, Muroyama A, Uehara S, Yamamoto $A$, et al. Vesicular inhibitory amino acid transporter is present in glucagon-containing secretory granules in alphaTC6 cells, mouse clonal alpha-cells, and alpha-cells of islets of Langerhans. Diabetes 2003;52:2066-74.

Herrera PL, Huarte J, Sanvito F, Meda P, Orici L, Vassalli JD. Embryogenesis of the murine endocrine pancreas; early expression of pancreatic polypeptide gene. Development 1991;113:1257-65.

Kaung HL, Elde RP. Distribution and morphometric quantitation of pancreatic endocrine cell types in the frog, Rana pipiens. Anat Rec 1980;196:173-81.

Kaung HL. Electron microscopic immunocytochemical localization of glucagon and pancreatic polypeptide in rat pancreas: characterization of a population of islet cells containing both peptides. Anat Rec 1985a;212:292-300.

Kaung HL. Glucagon and pancreatic polypeptide immunoreactivities co-exist in a population of rat islet cells. Experientia 1985b;41:86-

Lozano MT, Garcia Ayala A, Abad ME, Agulleiro B. Pancreatic endocrine cells in sea bass (Dicentrarchus labrax L.) I. Immunocytochemical characterization of glucagon- and PP-related peptides. Gen Comp Endocrinol 1991;81:187-97.

Louw J, Woodroof CW, Wolfe-Coote SA. Distribution of endocrine cells displaying immunoreactivity for one or more peptides in the pancreas of the adult vervet monkey (Cercopithecus aethiops). Anat Rec 1997;247:405-12.

Lukinius A, Ericsson JL, Grimelius L, Korsgren 0. Ultrastructural studies of the ontogeny of fetal human and porcine endocrine pancreas, with special reference to colocalization of the four major islet hormones. Dev Biol 1992;153:376-85.

Orci L, Baetens D, Ravazzola M, Stefan Y, Malaisse-Lagae F. Pancreatic polypeptide islets and glucagon islets: distinct topographic distribution in rat pancreas. C R Acad Sci Hebd Seances Acad Sci D 1976;27;283:1213-6.

Oshima H, Taketo M M, Oshima M. Destruction of pancreatic beta-cells by transgenic induction of prostaglandin E2 in the islets. $\mathrm{J}$ Biol Chem 2006 Sep 29;281:29330-6.

Park IS, Bendayan M. Coexistence of glucagon and pancreatic polypeptide in human and rat pancreatic endocrine cells. Endocrine Pathology1992:3:134-43.

Sundler F, Håkanson R, Larsson LI. Ontogeny of rat pancreatic polypeptide (PP) cells. Cell Tissue Res 1977 Mar 16;178:303-6.

Wilson ME, Yang KY, Kalousova A, Lau J, Kosaka Y, Lynn FC, et al. The HMG box transcription factor Sox4 contributes to the development of the endocrine pancreas. Diabetes 2005;54:3402-9.

Wolfe-Coote SA, Louw J, du Toit DF. Preliminary observations on the co-existence of regulatory peptides in cells of the baboon endocrine pancreas. Experientia 1988;15;44:238-40

Yang L, Li S, Hatch H, Ahrens K, Cornelius JG, Petersen BE, Peck AB. In vitro trans-differentiation of adult hepatic stem cells into pancreatic endocrine hormone-producing cells. Proc Natl Acad Sci USA 2002;99:8078-83.

Yoshinari M, Daikoku S. Ontogenic appearance of immunoreactive endocrine cells in rat pancreatic islets. Anatomy and Embryology 1982;165:63-70.

Zhang W, Efanov A, Yang SN, Fried G, Kolare S, Brown H, et al. Munc18 Associates with syntaxin and serves as a negative regulator of exocytosis in the pancreatic beta-cell. J Biol Chem 2000;275: 41521-7. 
Y.H. Huang et al.

86 